\title{
NEW ANTLER, SHELL, AND TOOTH TECHNOLOGY FROM LA GROTTE DU PLACARD (COMMUNE DE VILHONNEUR, CHARENTE)
}

\author{
Michelle C. LANGLEY and Christophe DELAGE
}

\begin{abstract}
The cave of Le Placard (Charente) has been explored by numerous generations of scholars over the past 150 years. These various explorations have exhumed a vast quantity of archeological material disseminated in public museums and private collections. Some have been the subject of detailed examination and published, but many are yet to be fully inventoried, let along thoroughly studied. This chapter provides an inventory and analysis of two such unpublished collections - curated at the Fine Arts Museum and at the Museum of the Archeological and Historical Society of the Charente - both located in Angoulême. The archeological material presented here includes various items of osseous industry, a pendant, and two shark teeth manuports.
\end{abstract}

\section{KEYWORDS}

Magdalenian; Le Placard; Antler; Shark; Projectile technology; Ornamentation; Engravings; Symbolism

\section{INTRODUCTION}

In recent years, the departmental council of Charente, owner of the site since the late 1980s, has worked hard to make Le Placard available to the general public by opening it to visits during two summer months and the weekend of European Heritage Days in mid-September. With reason, the emphasis of these visits is on the artistic dimension of this prehistoric habitat - parietal art in the form of fine engravings on the limestone walls of the cave dating to the Upper Solutrean, a phenomenon rare in the region (Clottes et al. 2010).

However, one hundred years of 'scratching' and formal excavations undertaken before the 1980s has revealed remnants of a very different nature, which remind us that Le Placard is much more than a case for engraved signs whose interpretation is delicate. It is well known that after the initial explorations (J. Fermond, A. de Maret) following discovery some 150 years ago, the site was effectively ransacked up to the mid-1980s, though scientific excavations also proceeded first in the $1960 \mathrm{~s}$ (1958-68, J. Roche) and then in the 1990s (J. Clottes, J. Airvaux, V. Feruglio). The artefacts recovered from both the legal and illegal excavations were dispersed among museums and private collections not only throughout France, but also abroad making the task of locating all of its products a near impossibility (Clottes et al. 2010: 348; Debénath 2009: 106; Octobon 1926: 233; Patte 1941: 55; Roche 1963: 75). Indeed, even among the known collections, many are yet to be fully inventoried, let along thoroughly studied and published. This paper provides an inventory and analysis of two such unpublished collections - curated at the Musée des
Beaux-Arts (Fine Arts Museum) and at the Musée de la Société Archéologique et Historique de la Charente (SAHC; Archaeological and Historical Society of Charente) both located in Angoulême, some $30 \mathrm{~km}$ west of the Palaeolithic site. The archeological material presented here includes various items of osseous industry, a pendant, and two shark teeth manuports.

The osseous industry of Le Placard has been the subject of numerous studies. The first such data were rather briefly published by Jean Fermond (1873) and Arthur de Maret $(1878,1879,1880)$, followed by a more detailed study carried out by Adrien de Mortillet $(1906,1907)$. But the most noteworthy studies (in terms of both descriptions and illustrations) are to be attributed to Gustave Chauvet (1910) and Henri Breuil (1913; Breuil and de Saint-Périer 1927). Following an important sorting of the de Maret collection at the Musée des Antiquités Nationales in the 1950s, several studies focusing on the osseous industry were conducted in the 1970s. Emilienne Genet-Varcin (1968) started with a small sample of spear points and baguettes, some of which carried parallel incisions, notches, or engravings. Some of the numerous bâtons percés were then the subject of various (technological, typological, functional) analyses (Delporte 1970; Mons 1976). A sample of 37 items interpreted as lissoirs were also the focus of attention (Mons and Stordeur 1977). This latter study combined various approaches (i.e., morphological, morphometric, functional, and chronological) to understand the temporal and techno-functional specificities of this heterogeneous group of artefacts. That same de Maret collection was the subject of additional studies by the same team (Leroy-Prost 1977; Mons 1980; Mons 
and Kandel 2000). Later on, the bâtons percés (Lompré 2003) and the spearthrowers (Cattelain 2004, 2014) were the focus of specific and detailed observations. To conclude this brief survey we should also mention various academic theses which describe a whole range of raw materials (i.e., cervid bones and antler, as well as ivory) and techniques used to produce a wide array of utilitarian and symbolic artefacts (Chech 1974; Douche 2004; Pignolet 2013).

Shells were abundantly recovered from the earliest explorations by Jean Fermond and Arthur de Maret. The shell assemblage was first analysed by P. Fischer and then briefly published by Fermond (1874) and de Maret (1880, 1881; see also Fischer 1879). Thus, the presence of perforated Pecten maximus at Le Placard was first mentioned by Fermond (1874, note 1). A few years later, H. Fischer (in de Maret 1880: 172, 1881: 229) identified three more, similarly perforated. Emilienne Genet-Varcin (1968: 237, Fig. 2, no.22-26) also identified valves of Pecten, scallop, and Cardium. Yvette Taborin (1972) studied first a series of perforated Cardium before her doctoral research presented significant data on the nature of this assemblage and its techno-functional aspects, as well as data on the origin of these shells (Taborin 1992, 1993).

Finally, the presence of shark (Carcharodon) teeth at Le Placard has been previously documented by Jean Fermond (1874: 8) and Arthur de Maret (1880: 174, 1881: 230).

\section{DESCRIPTION OF THE NEW MATERIAL}

The new material found in the Musée d'Angoulême and the Musée de la SAHC is dominated by pieces of antler projectile point technology, though several other domestic or social technologies are also present and are described in the following sections.

\section{Projectile Points}

In total, 92 fragments of antler projectile point technology were examined (Table 1). At least three - but likely four - types of weaponry were observed: baguettes demi-rondes, double-bevel based points, single-bevel based points, and antler/lithic composites.

Evidence for the working of reindeer antler on site is found in a small antler tine with pedicle attached (providing evidence for raw material being brought to the site), along with several artefacts which display the characteristic traces of the groove-and-splinter technique (see example in Figure 3, no.19). Others are roughly made on minimally worked pieces (Figure 1), perhaps suggesting that there was a surplus of raw material on site.
While three examples of baguettes demi-rondes were present in this new collection, single-bevel based points constituted the largest sub-set of projectile point fragments identifiable to type, including three largely intact examples (Figure 3, no.1, Figure 4, no.5, Figure 7, no.5). The predominance of mesial-proximal fragments of both this technology and the double-bevelled variety, along with numerous distal-mesial fragments (Figure 2) which could have originated from either of these two types is consistent with discarded weaponry fragments that were broken in use before being returned to the site. Also consistent with this interpretation is the appearance of several distal-mesial fragments with worked fractures (déchets de sectionnement par raclage et flexion; Chauvière 2016; Chauvière and Rigaud 2005; Rigaud 2006) (Figure 2, no.1, 2, 3), along with the fact that around half of the points exhibit impact induced fractures on their proximal extremities.

Recycling is also evident with two artefacts reused as 'wedges' (Figure 4, no.2 and 6) - characterised by severe crushing and mushrooming on both their distal and proximal extremities - and which is a common form of projectile point recycling observed in assemblages across the Magdalenian territory (Langley 2015; Langley et al. 2016; Pétillon 2006). Also consistent with other large assemblages of Magdalenian osseous projectile technology (i.e., Isturitz, La Vache; Langley 2015) is the presence of a more gracile group of points (Figure 3) - a sub-set widely recognised in the literature (e.g., Allain and Rigaud 1992; Pétillon et al. 2011; Weniger 1992, 2000).

A number of the point fragments feature deep longitudinal grooves and/or grouped striations suggesting that they constitute the antler core of a composite antler/lithic projectile point (Figure 5; Allain and Rigaud 1986; Bosinski 2010; Houmard 2003; Houmard and Jacquot 2009). Such composite points are one of the most common categories of Upper Palaeolithic projectile points, and have been demonstrated to be extremely efficient hunting weapons (Pétillon et al. 2011).

A feature of the small Angoulême collections is the engraved designs present on most of the weapon fragments. Figure 6 presents a sample of these artefacts showing the range of designs observed. The most common design element in this collection is a series of short striations seemingly haphazardly cut into the superior surface of the point (Figure 6, no.1-2, 8-9). These striations are not consistent with incidental cut marks which a point may suffer in the course of being cut free of caught targets. Instead, they far more numerous and distributed over the superior surface of each implement (Langley 2015; Pétillon 2006; Pétillon and Letourneux 2003). Other linear designs, more carefully executed (Figure 6, no.3-4, 11-12), along with several examples of curved lines (Figure 6, no.5, 13) 


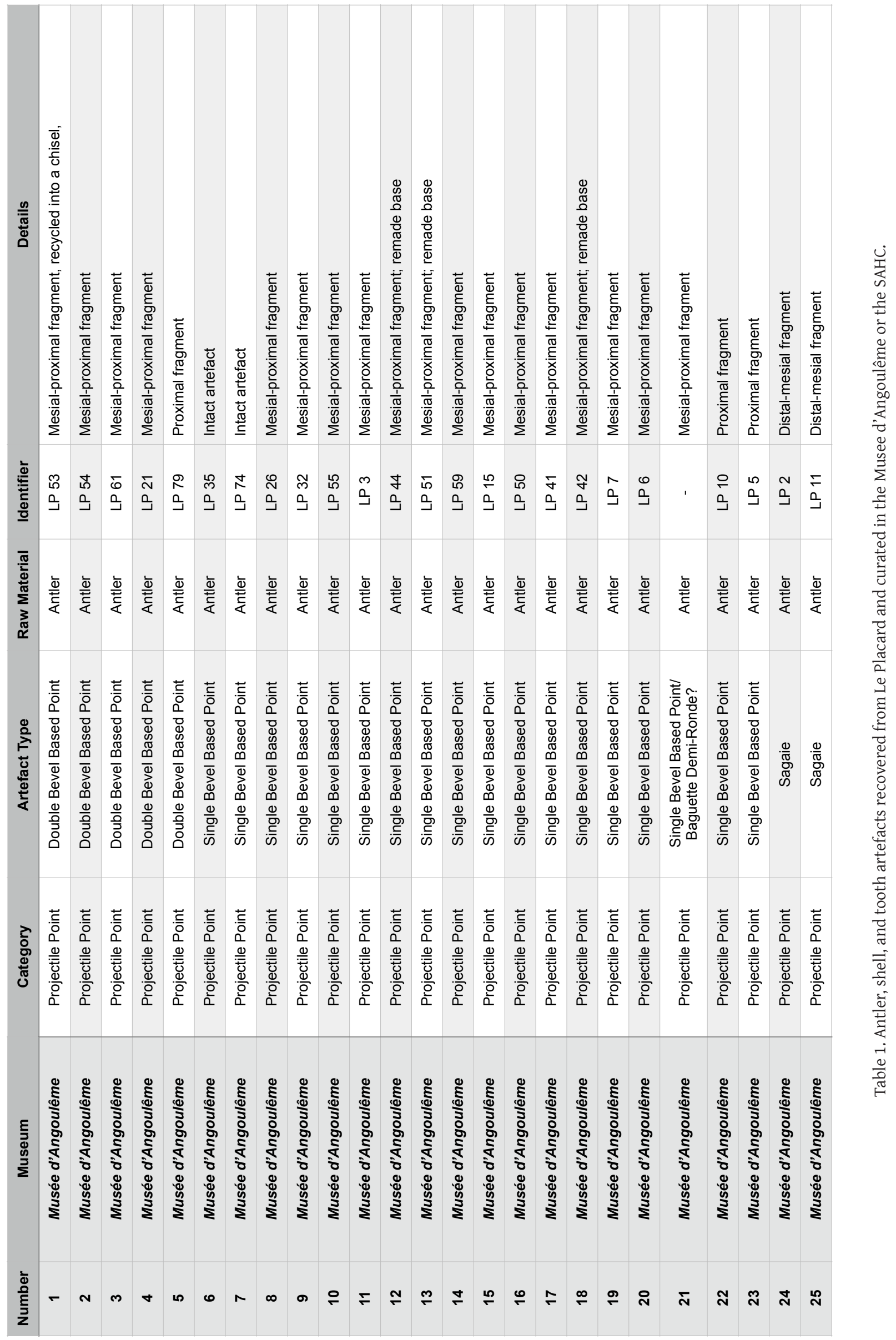




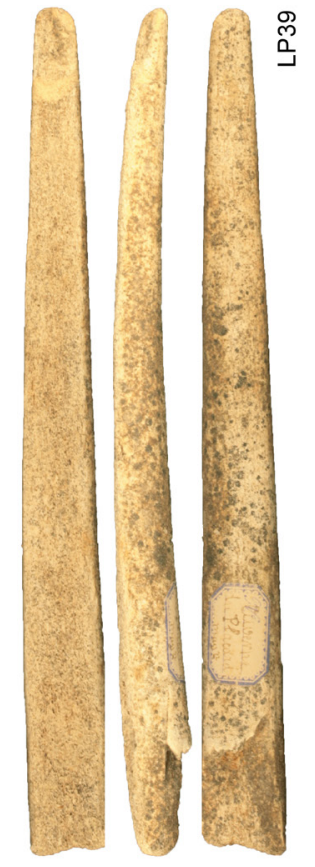

1

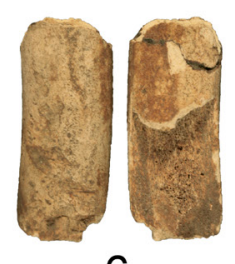

6

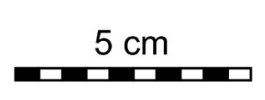

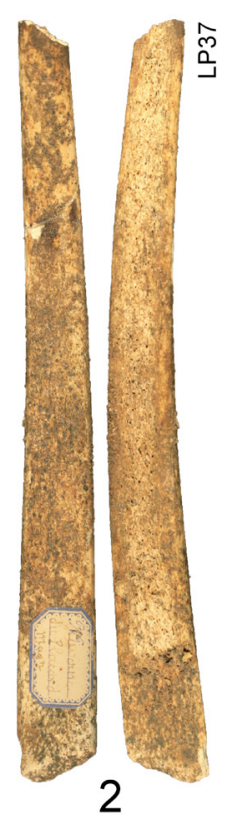
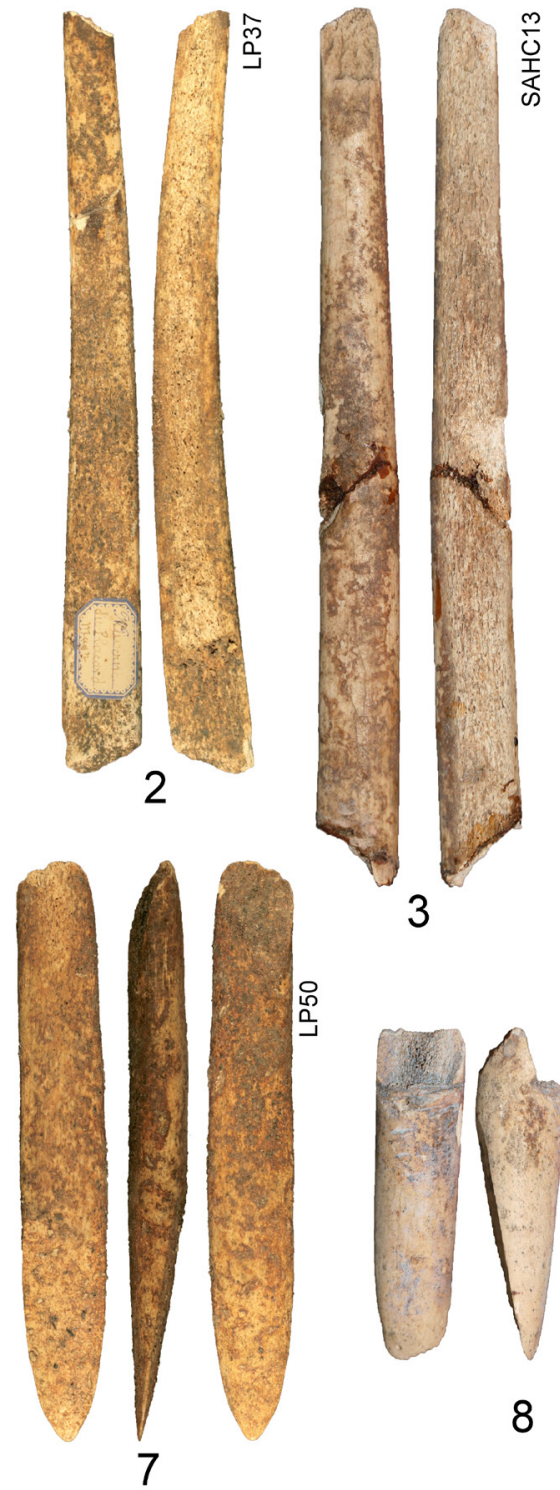
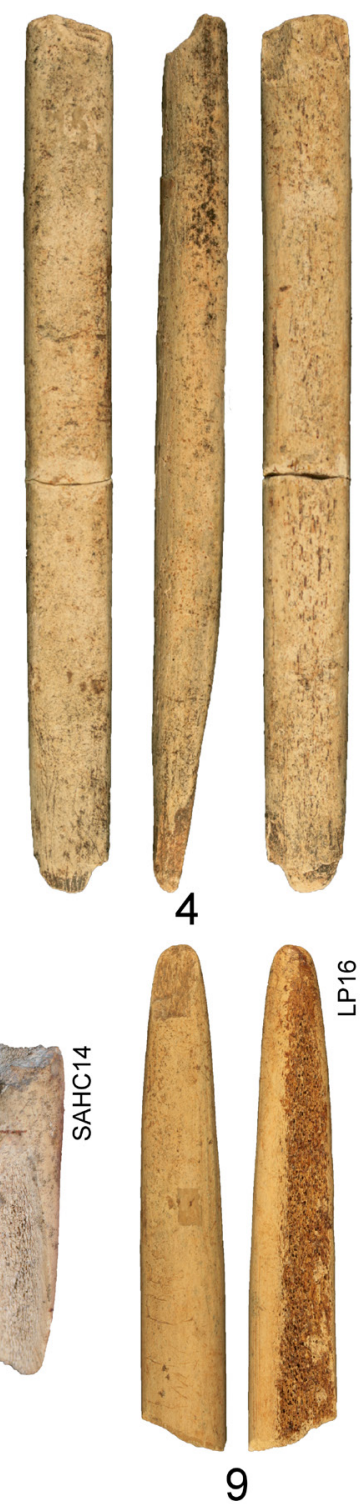
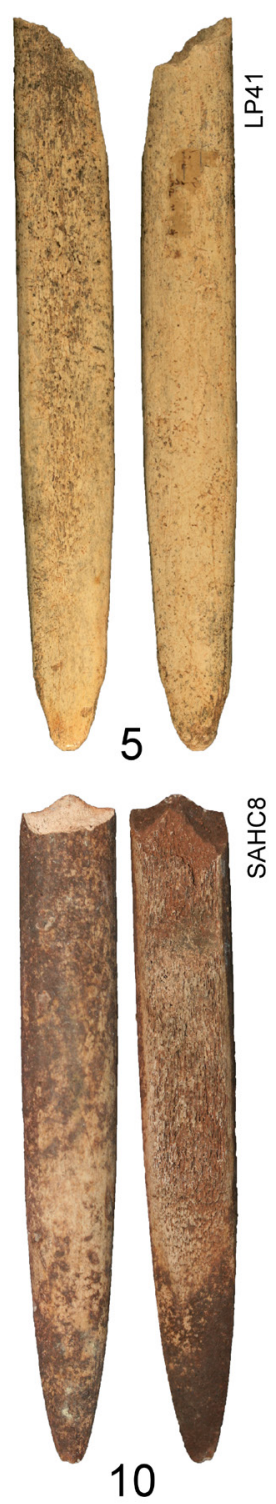

Figure 1. Reindeer antler minimally modified into points.

were also observed. One large fragment of a baguette demi-ronde (Figure 3, no.7) displays a more complex design executed with a burin and using single deep strokes to create each line. Particular designs do not appear to be tied to weapon tip form (such as singlebevel or baguette demi-ronde).

\section{Lissoir}

A large antler fragment exhibiting longitudinal subparallel striations down two sides and a rounded and highly polished extremity was found in the SAHC collection (Figure 7, no.1). Though the piece is exceptionally large, the use wear is consistent with this artefact having been used as a lissoir, a tool commonly connected to hide-working (Averbouh and Buisson 1996), and one that has already been reported for Le Placard (e.g., Mons and Stordeur 1977).

\section{A Bull Roarer, a Spatula, or a Pendant?}

The function of one artefact is not immediately apparent from either its morphology or visible use wear. Shown in Figure 7, no.2, this item is a carefully shaped ovaloide approximately $11 \mathrm{~cm}$ in length and almost 2 $\mathrm{cm}$ at its widest point. It is made on a particularly large antler tine as evidenced by the $>1 \mathrm{~cm}$ thick cortical tissue which constitutes most of the piece. A cleavage fracture is found at one extremity and occurred prior to deposition. Examination of its intact curved end found no evidence consistent with use as a projectile tip, while its form is not consistent with known Magdalenian projectile point types. Furthermore, projectile points made on antler both from this site and from all other Magdalenian sites always have the spongiosa tissue covering the lower (inferior) surface of the weapon tip, rather than on one side as is the case with this 

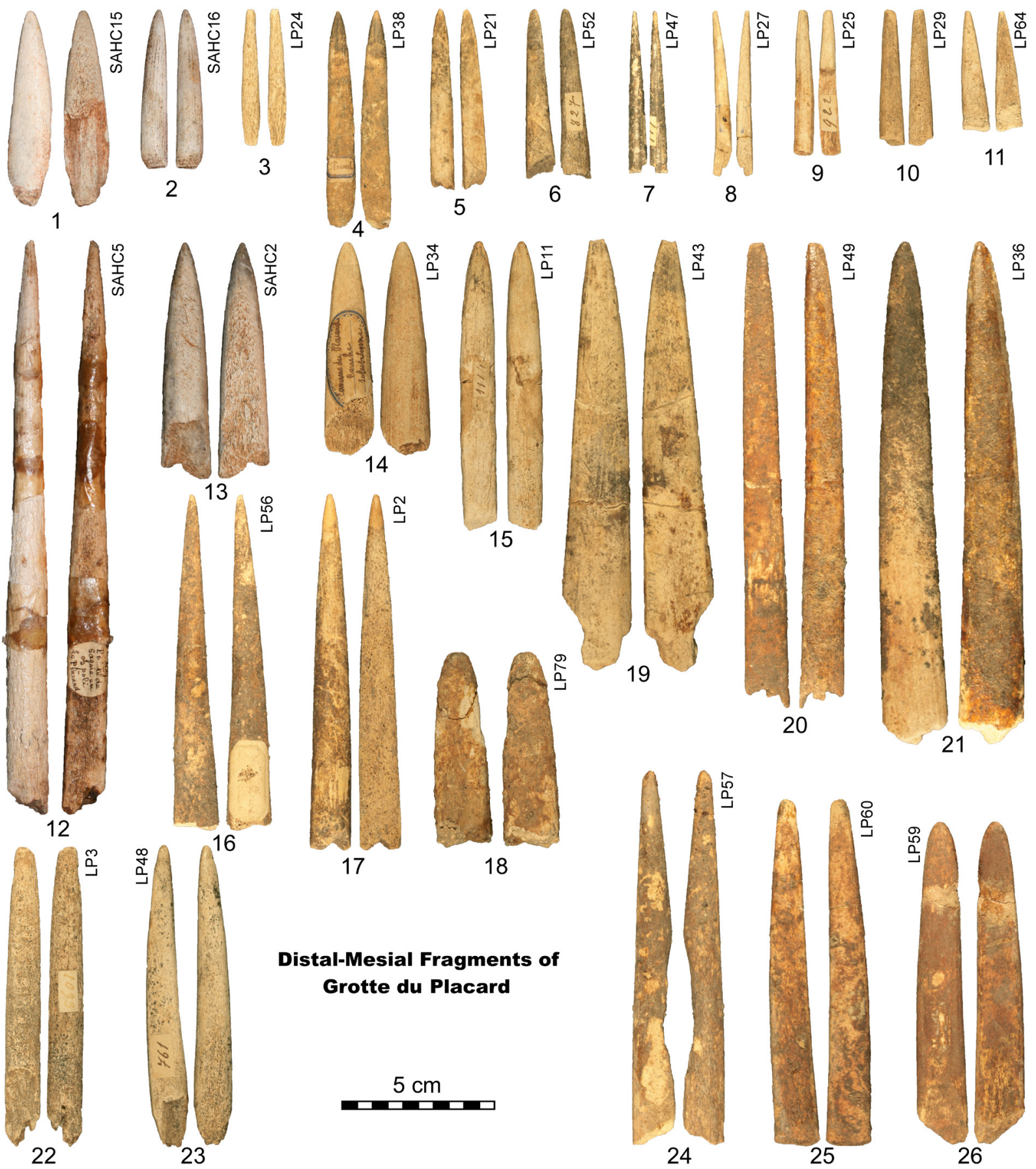

\section{Distal-Mesial Fragments of Grotte du Placard}

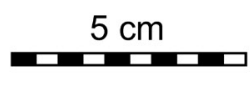

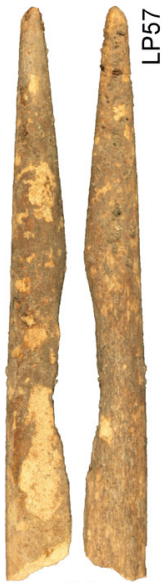

24

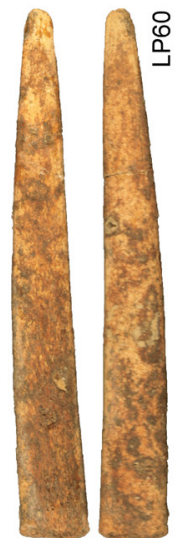

25

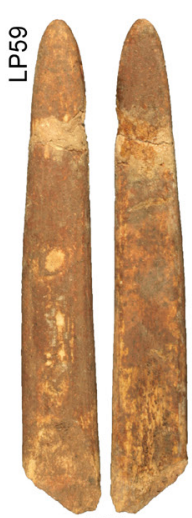

26

Figure 2. Distal-mesial fragments curated in the Museum of Angoulême and Musée de la SAHC.

particular artefact. Consequently, we do not believe this artefact to be another projectile weapon tip.

Based on the careful shaping of the artefact and its overall morphology we came up with three possibilities as to its function. The first is that it may be a form of ornamentation, though no perforation evidence for attachment was observed. Second, it may be another example of a spatula, though those previously identified as such in the literature have more of a 'scoop' on one end. Finally, it may be a bull roarer as those previously reported from Upper Paleolithic European contexts such as that from La Roche de Birol and Laugerie-Basse (both Magdalenian), and Lespugue and Badegoule (both Solutrean) - feature a similar ovaloide shape, similar length, and gently curved surfaces, though the Le Placard implement appears slimmer than these other examples (Bahn 1997; Dauvois 1989). Again, however, the artefact does not have a perforation which might support this notion, though such a feature may have 

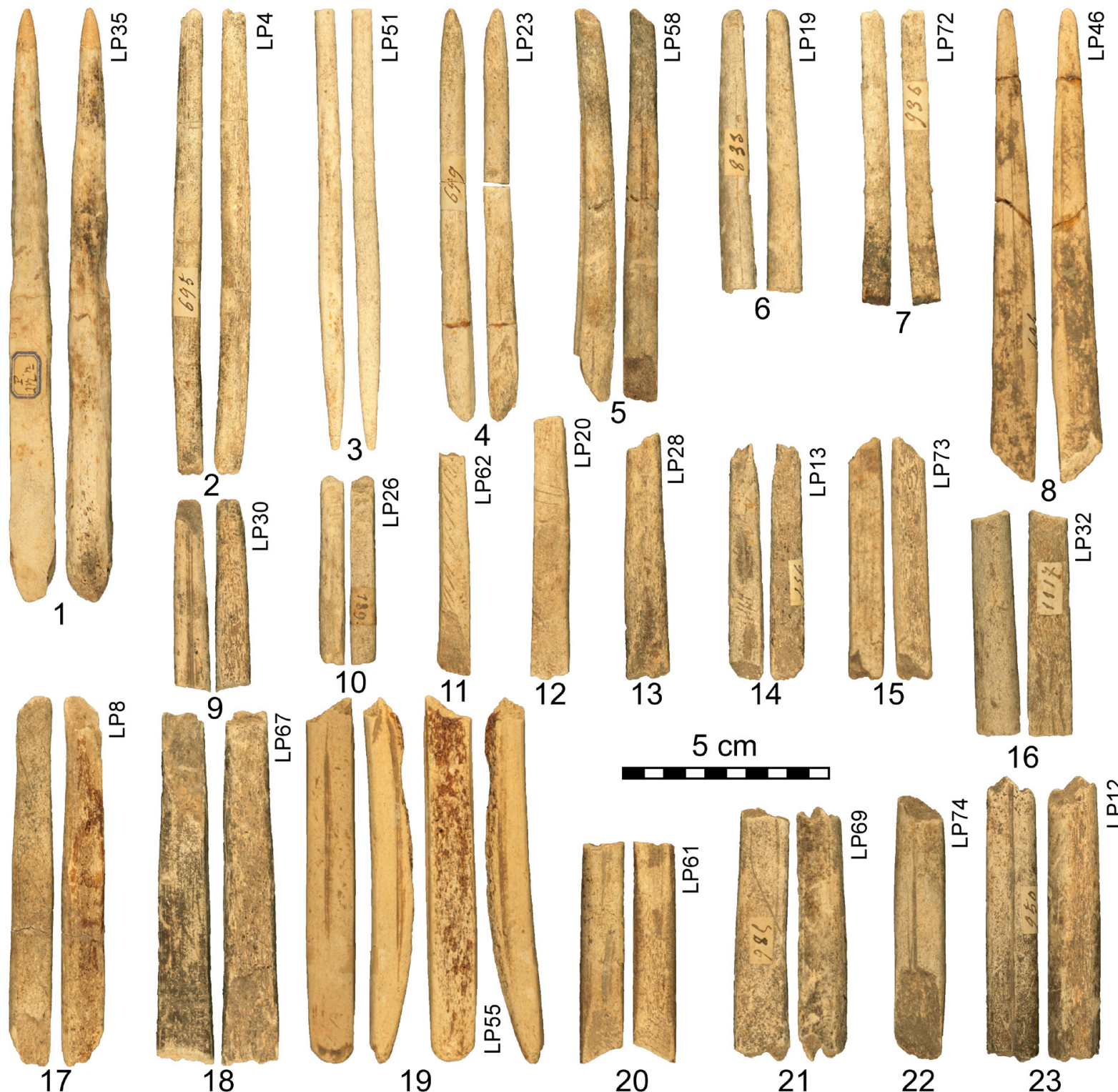

19
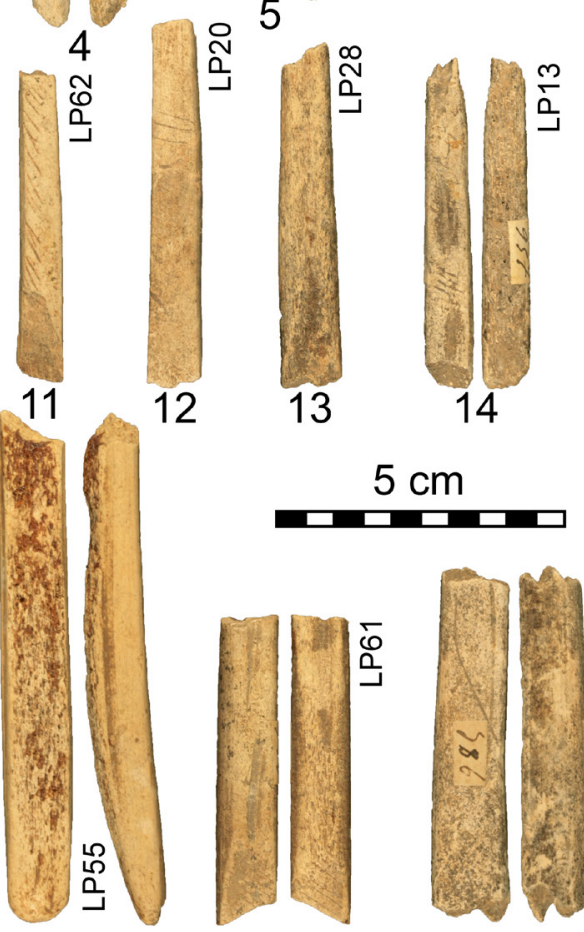

20

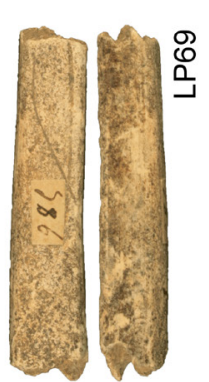

21

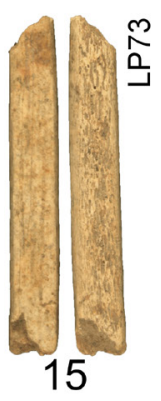

16

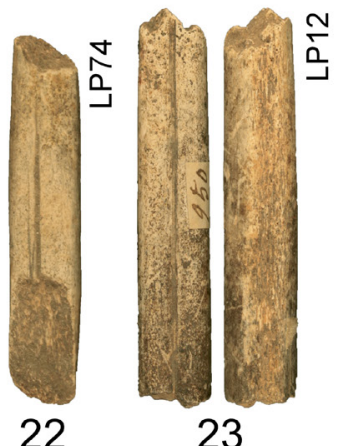

Figure 3. Intact and fragments of gracile projectile points.

been removed when the artefact broke in prehistory. Furthermore, attachment of either an ornament or a bull roarer to a string does not necessarily require a perforation.

\section{Pendant}

A large valve of the species Pecten maximus (Linné, 1758) with two small holes perforated through its umbo constitutes the only clearly ornamental piece from the Angoulême Le Placard collections (Figure 8, no.1). Shellfish are quite rare at Le Placard and Y. Taborin has already described 21 of such Pecten shells from de Maret's and Daniel's excavations (Taborin 1993: 288294, 408, 437). These items are mainly dated to the Magdalenian (undifferentiated), but their presence cannot be excluded from the Solutrean.
Perforated from the exterior surface, the two holes of the Pecten under consideration here are roughly aligned. In general, these shells have only one perforation through the umbo; whereas here we have two perforations in this location. Only one other Pecten features a double perforation like the new Le Placard example, that coming from the cave of Mal Carré in Caniac (Taborin 1993: 288). However, in Caniac, the perforations are located not on the umbo, as usual, but on the left wing of the valve.

Since these perforated Pecten are relatively large objects, one cannot dismiss the hypothesis of a tool or at least a utilitarian context. Yet they were not used as containers (for colourants, for example). These items may have been strung in a fashion similar to that suggested by Taborin (1972) for a Cardium shell 


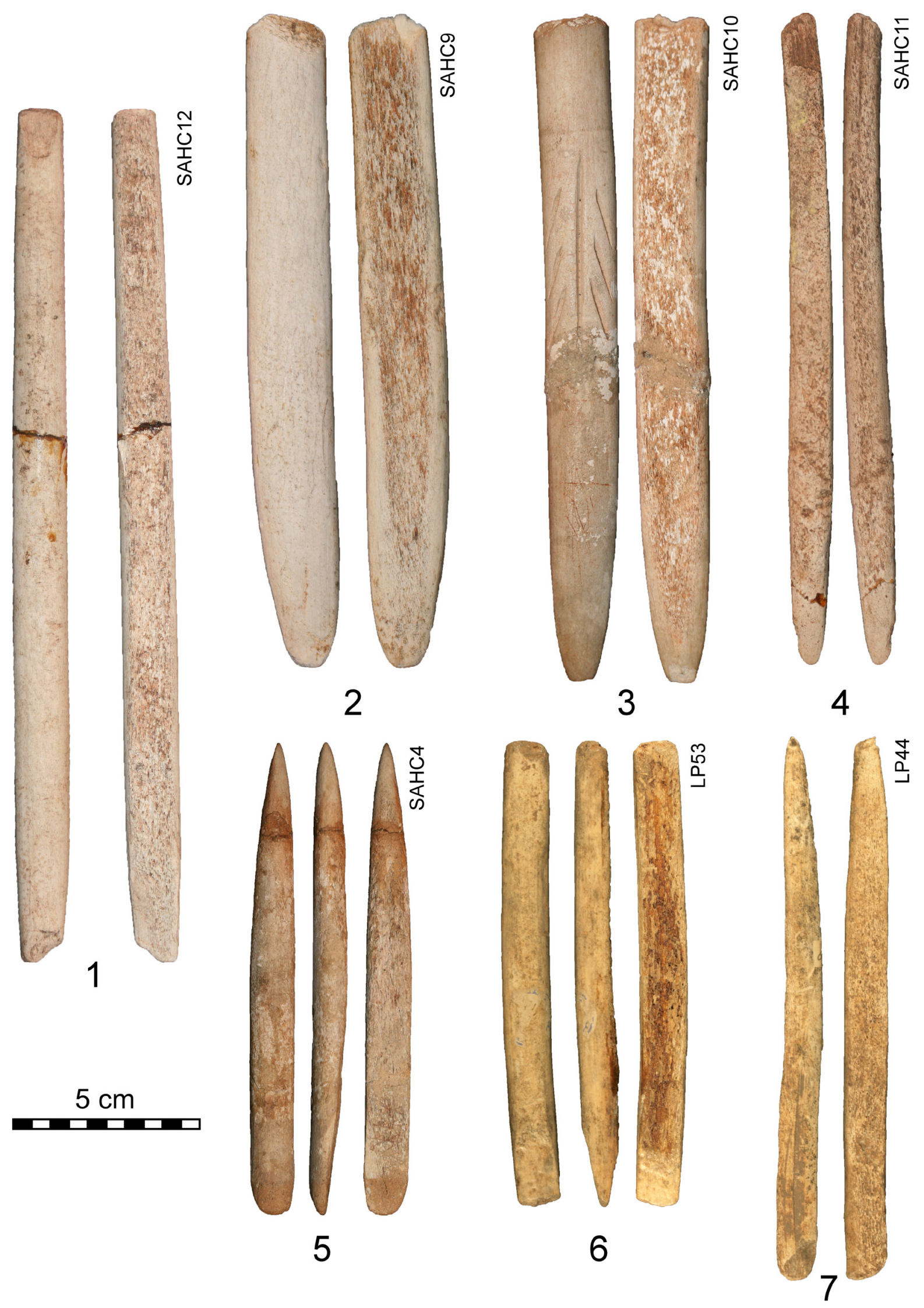

Figure 4. Some of the more complete projectile points curated in the Museum of Angoulême and Musée de la SAHC. 


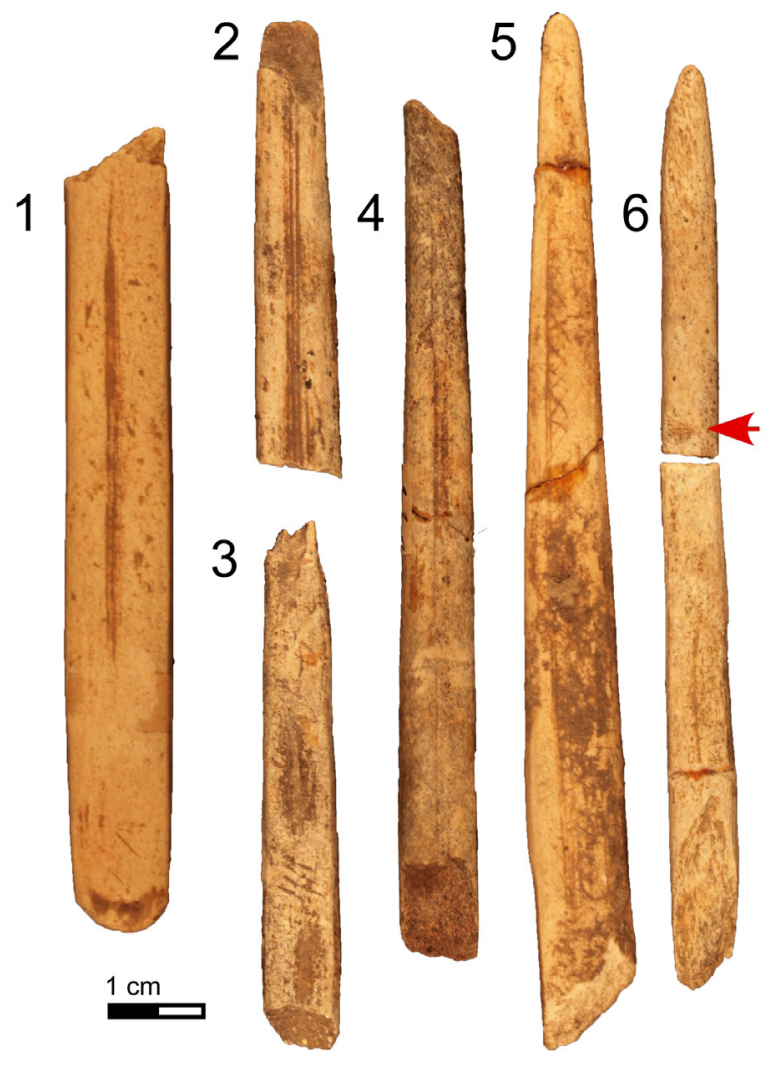

Figure 5. Examples of antler points featuring lateral grooves and/ or cross-hatched facets (one example indicated by red arrow) possibly examples of antler/lithic projectile weapon tips. similarly perforated and also recovered from Le Placard (see Figure 9). Such Pecten suspended through two holes would rest more balanced and stable, unlike objects with a single perforation (Taborin 1993: 293-294). Thus, they could have been worn as ornaments.

The Atlantic coast was around 250km from Le Placard as the crow flies during the Last Glacial Maximum (LGM), and these shells might have been collected from the similarly distant Pliocene (Redonian) fossil deposits in Oléron or Vendée (Taborin 1993: 49, 407, fig. 33). Similar deposits are also present in the lower Loire valley and Anjou, about $250 \mathrm{~km}$ to the north-west of Le Placard. This shell may equally have been obtained from even further south from which significant quantities of marine raw materials have been excavated (such as at Isturitz; Pétillon 2008, 2013) or via down-the-line trade as it is known that a significant social and trading network was operating throughout the Magdalenian (e.g., Bahn 1982a; Conkey 1980; Jochim 1987).

\section{Fossil Shark Teeth}

Finally, two fossil shark teeth, the larger of which is broken down its length, were included in the Musée d'Angoulême collection studied (Figure 8, no.2 and 3). As described by Bahn (1977, 1982a, 1982b), fossils have frequently been recovered from Magdalenian deposits in western Europe, stating that while identification
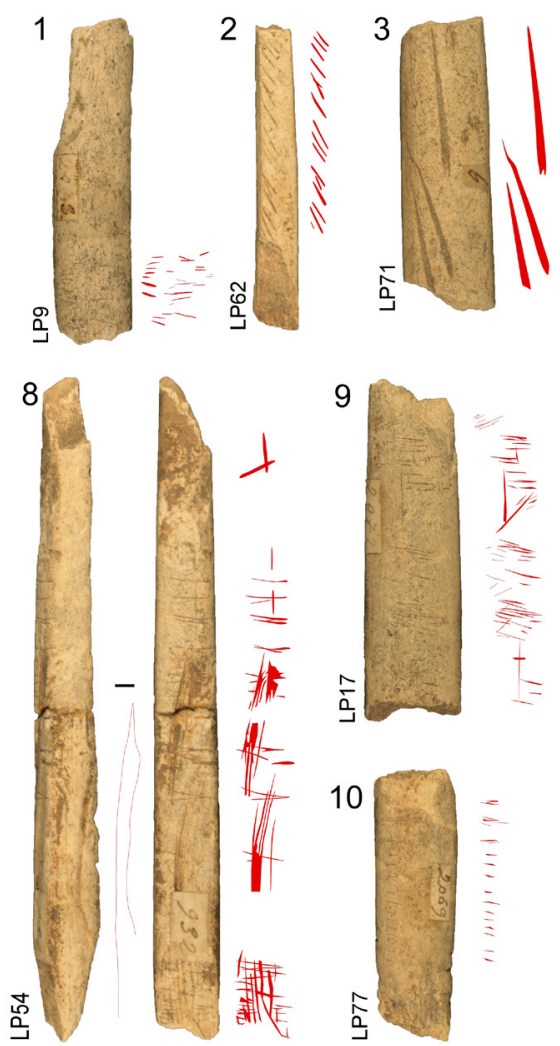

9

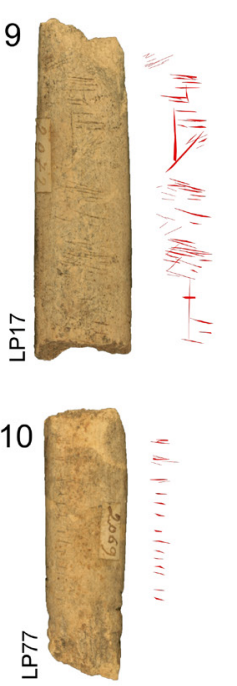

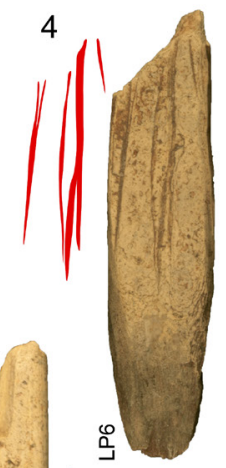

5
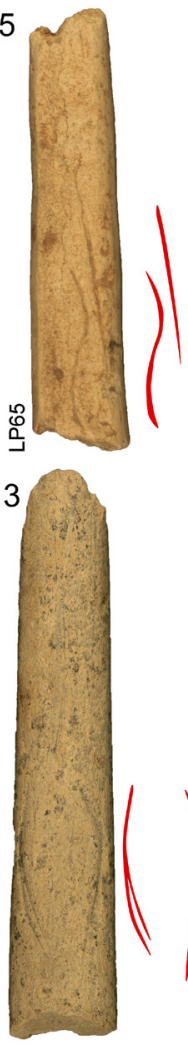
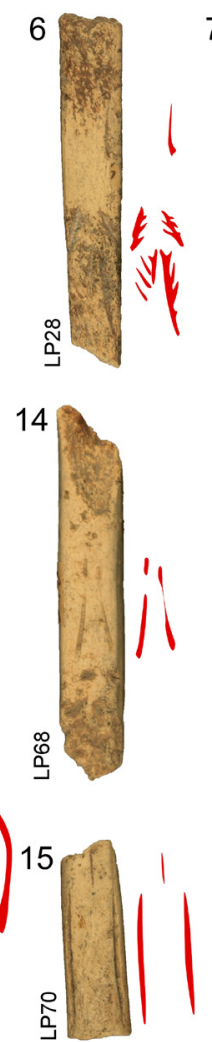

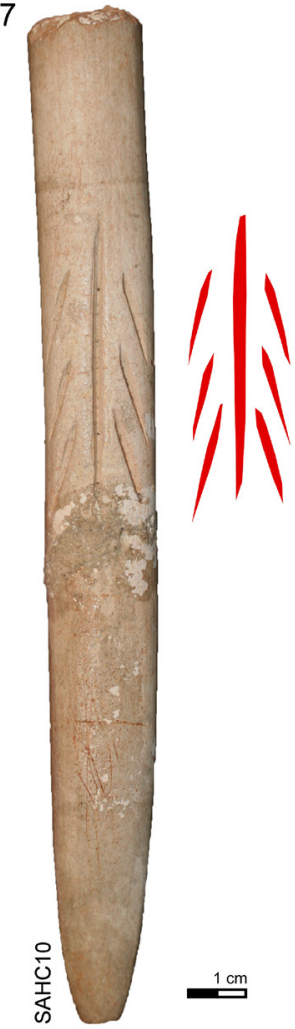

Figure 6. Range of engraved decoration observed on the new Le Placard points described here. 


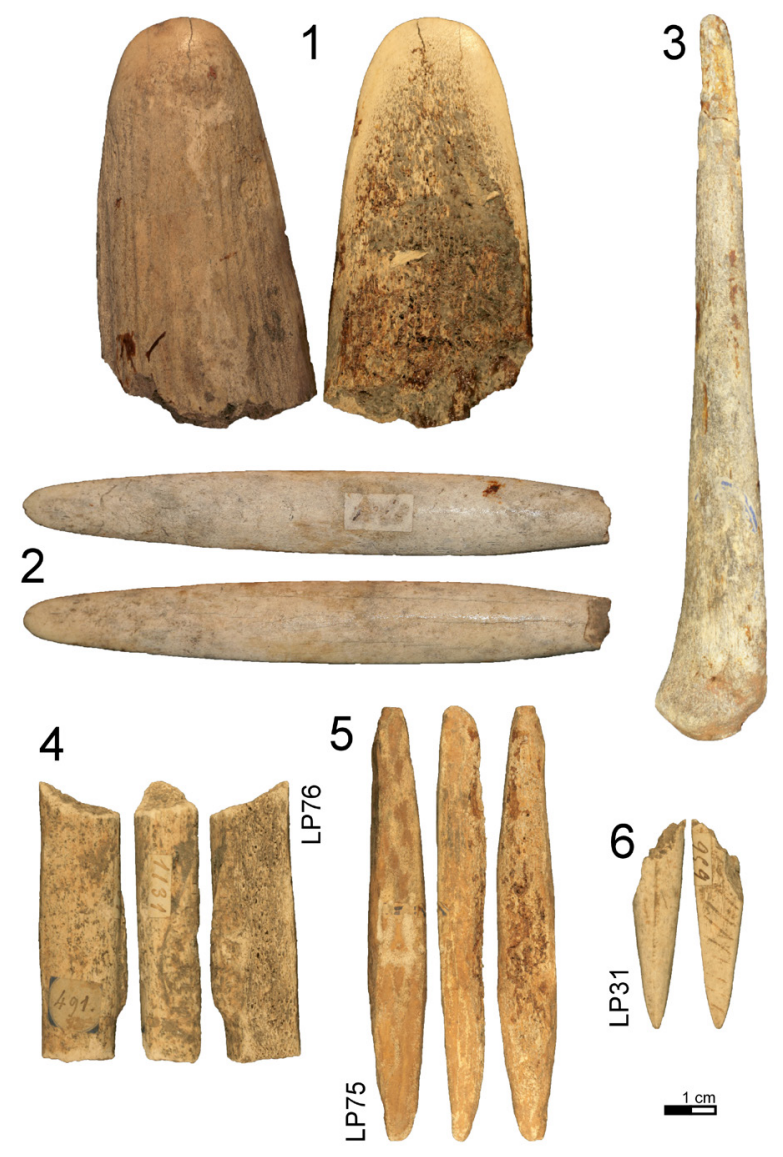

Figure 7. Other antler technologies found in the Museum of Angoulême and Musée de la SAHC.

of source-beds is rarely definite, it seems apparent that at least some of these specimens were moved considerable distances. Bahn (1977) also mentions that fossils recovered from sites in southwest France seem to have been collected from three major sources, with beds in Anjou and Touraine, the likely source of fossil shells found at Laugerie-Basse and La Madeleine. Given that these fossil beds are significantly closer to Le
Placard than to the Dordogne sites just mentioned, it seems possible that the teeth were sourced here.

Finally, it should be noted that fossil shark teeth, in particular, are reportedly quite common in Magdalenian deposits (Eriksen 2002) and include sites such as Mas d'Azil (Bahn 1982a), Isturitz (Oakley 1965), along with Gönnesdorf in the central Rhineland (Bosinski 1975, 1981).

\section{CONCLUSION}

E. Genet-Varcin (1968: 544) said about the project of the Musée des Antiquités Nationales led by L. Mons in the 1970s that this work did not bring many novelties concerning the archeological remains of Le Placard compared to the work originally published by A. de Maret and A. de Mortillet. These comments could also apply to our contribution. However, even if Genet-Varcin is right, it is still important to continue to locate the scattered collections of Le Placard, to study them in detail and to publish them if we are to build a comprehensive understanding of Upper Palaeolithic France and the wider region of Western Europe. Consequently, these two small collections of the Musée des Beaux-Arts and the Musée de la SAHC, both in Angoulême, are worthy of acknowledgment in the literature.

In conclusion, these collections confirm, yet again, the richness of this extraordinary site. In fact, every time a researcher has conducted explorations at Le Placard, whether in the cavity or on the slope in front, and whether extensive excavations or explorations limited to a few hours on a Sunday afternoon were undertaken, $\mathrm{s} /$ he has exhumed remains of all kinds, utilitarian or non-utilitarian. Such findings raise serious questions regarding the nature and duration of the activities that took place at Le Placard.
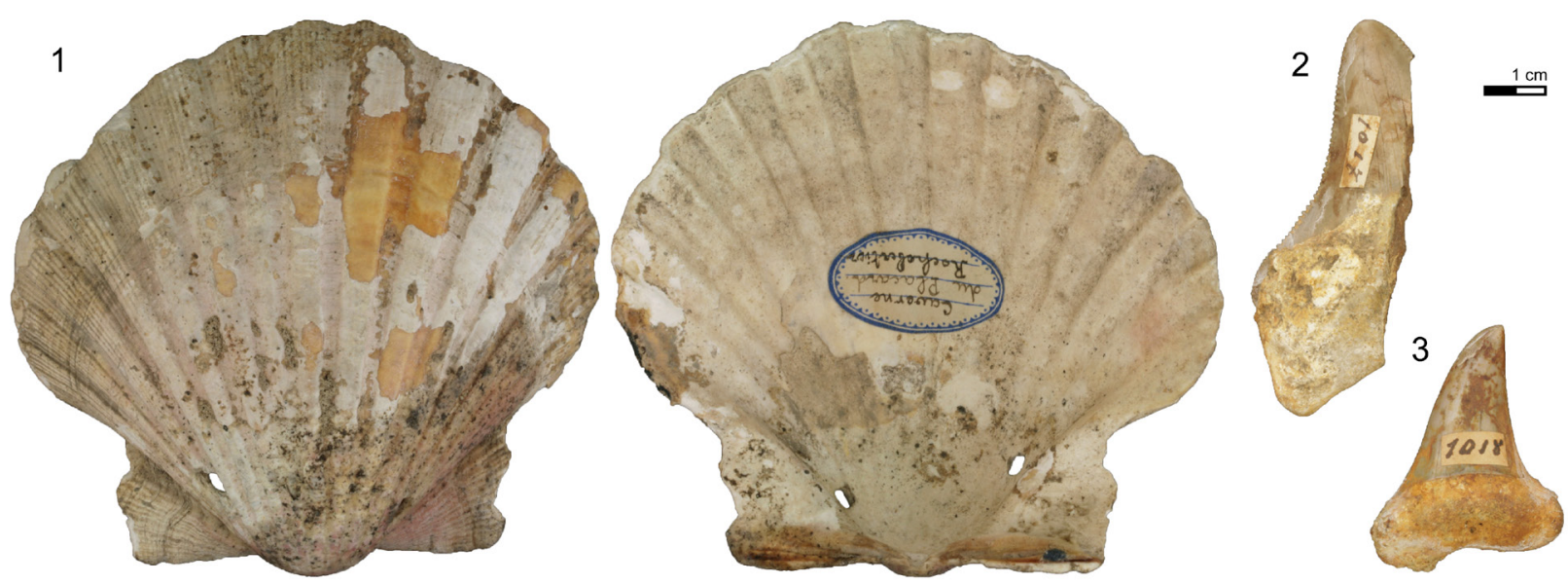

Figure 8. Perforated Pecten maximus and collected fossil shark teeth from Le Placard. 

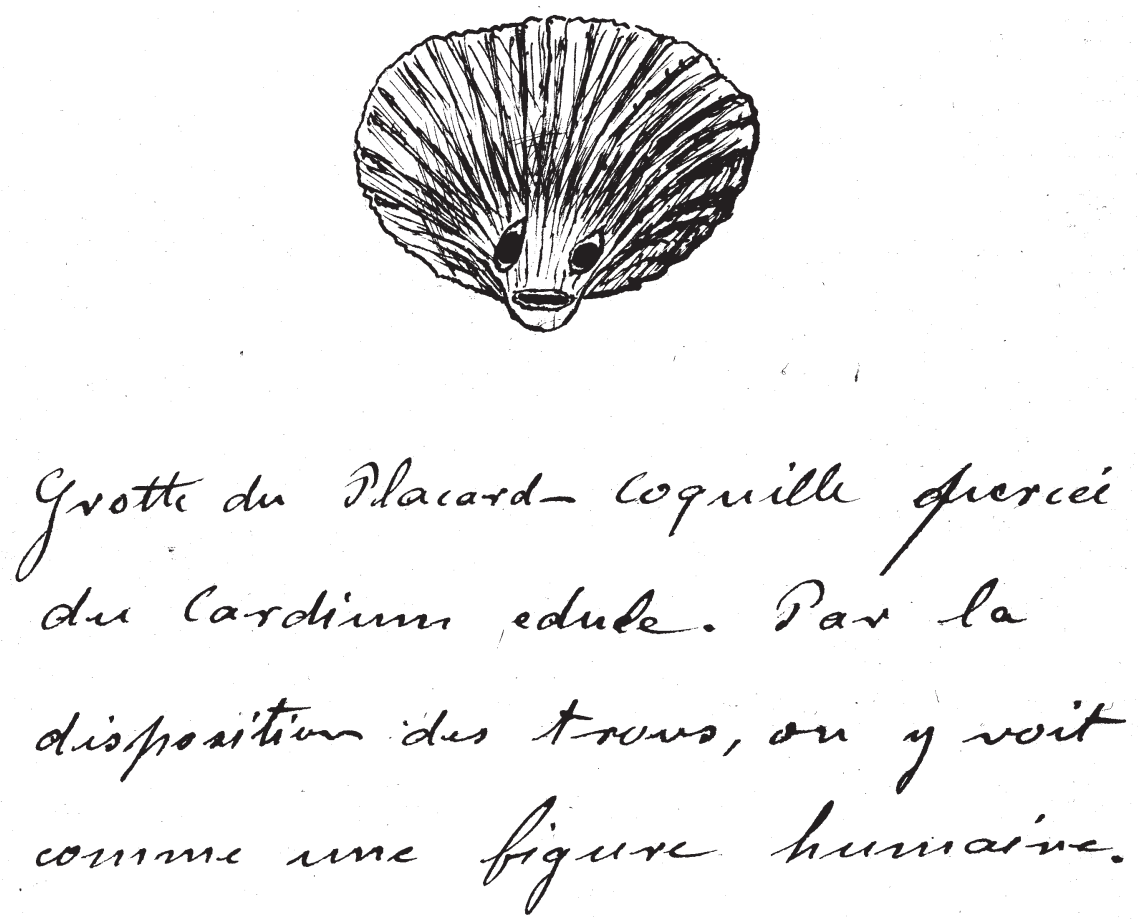

Figure 9. Perforated Cardium, certainly from de Maret's excavations (De Mortillet Archives, Saarland University, Saarbrücken, Germany).

\section{ACKNOWLEDGEMENTS}

We are pleased to thank J.-F. Tournepiche, J. Gomez de Soto, and D. Augier for granting us access to these two collections in Angoulême and for all of their assistance with the study. We also thank R. Echt for his permission to publish the illustration of Figure 9. The material presented in this paper was originally examined for MCL's DPhil project, undertaken at the Institute of Archaeology, University of Oxford. The Clarendon Fund (Oxford), Meyerstein Fund (Oxford), and The Boise Trust Fund (Oxford) are each thanked for their financial support of that project.

\section{REFERENCES}

Allain, J. and A. Rigaud 1986. Décor et fonction: Quelques exemples tirés du Magdalénien. L’Anthropologie (Paris) 90: 713-738.

Allain, J. and A. Rigaud 1992. Les petites pointes dans l'industrie osseuse de La Garenne: Fonction et figuration. L'Anthropologie (Paris) 96: 135-162.

Averbouh, A. and D. Buisson 1996. Approche morphofonctionnelle des objets nommés lissoirs: proposition d'une fiche analytique théorique. Antiquités Nationales 28: 41-46.

Bahn, P.G. 1977. Seasonal Migration in S.W. France during the Glacial Period. Journal of Archaeological Science 4: 245-257.

Bahn, P.G. 1982a. Inter-site and inter-regional links during the Upper Palaeolithic: The Pyrenean Evidence. Oxford Journal of Archaeology 1: 247-268.
Bahn, P.G. 1982b. Palaeolithic shell shock. Antiquity 56: 47-48.

Bahn, P.G. 1997. Journey through the Ice Age. London: Weidenfeld and Nicholson.

Bosinski, G. 1975. Ein fossiler Haifischzahn vom Magdalénien-Fundplatz Gönnersdorf. HeimatJahrbuch des Landkreises Neuwied 1975: 47-48.

Bosinski, G. 1981. Gönnersdorf, Eiszeitjäger am Mittelrhein. Führer zur Sonderausstellung des Landesmuseums Koblenz 1981, in Schriftenreihe der Bezirksregierung Koblenz Band 2.

Bosinski, G. 2010. The hafting of backed bladelets in the Late Magdalenian, in J.M. Burdukiewicz, K. Cyrek, P. Dyczek, and K. Szymczak (eds) Understanding the Past: Papers Offered to Stefan K. Kozlowski: 55-58. Warsaw: University of Warsaw.

Breuil, H. 1913. Les subdivisions du Paléolithique supérieur et leur signification, in W. Deonna (ed) Congrès International d'Anthropologie et d'Archéologie Préhistorique, Compte Rendu de la XIV session, Genève, 1912: 165-238. Genève: Albert Kündig.

Breuil, H. and R. de Saint-Périer 1927. Les poissons, les batraciens et les reptiles dans l'art quaternaire (Archives de l'Institut de Paléontologie Humaine, Mémoire 2). Paris: Masson et Cie, Éditeurs.

Cattelain, P. 2004. Un propulseur inédit de la Grotte du Placard (Vilhonneur, Charente, France). Notae Praehistoricae 24: 61-67.

Cattelain, P. 2014. Un propulseur inédit de la Grotte du Placard (Vilhonneur, Charente, France) provenant de la collection Breuil conservée à l'Institut de 
Paléontologie Humaine à Paris. Archéo-Situla 34: 41-42.

Chauvet, G. 1910. Os, ivoires et bois de renne ouvrés de la Charente. Hypothèses palethnographiques. Bulletins et Mémoires de la Société archéologique et historique de la Charente ( $8^{\circ}$ série) I: 1-184.

Chauvière, F.-X. 2016. Osseous projectile points in the Magdalenian: 'True' points versus pointed wasteproducts, in M.C. Langley (ed) Osseous Projectile Weaponry: Towards an Understanding of Pleistocene Cultural Variability (Vertebrate Paleobiology and Paleoanthropology): 161-169. Dordrecht: Springer.

Chauvière, F.-X. and A. Rigaud 2005. Les «sagaies» à «base raccourcie» ou les avatars de la typologie: du technique au «non-fonctionnel» dans le Magdalénien à navettes de la Garenne (Saint-Marcel, Indre), in V. Dujardin (ed) Industrie osseuse et parures du Solutréen au Magdalénien en Europe. Actes de la Table Ronde sur le Paléolithique supérieur récent, Angoulême (Charente), 28-30 Mars 2003 (Mémoire, 34): 233-242. Paris: Société Préhistorique Française..

Chech, M. 1974. Essai sur les techniques de débitage des bois de rennes au Magdalénien. Master's Thesis. Nanterre: University of Paris X-Nanterre.

Clottes, J., L. Duport, V. Feruglio and Y. Le Guillou 2010. La Grotte du Placard à Vilhonneur (Charente) (fouilles 1990-1995), in J. Buisson-Catil and J. Primault (eds) Préhistoire entre Vienne et Charente. Hommes et sociétés du Paléolithique (Mémoire XXXVIII): 345-358. Chauvigny: Association des Publications Chauvinoises.

Conkey, M.W. 1980. The identification of prehistoric hunter-gatherer aggregation: The case of Altamira. Current Anthropology 21: 609-630.

Dauvois, M. 1989. Son et musique paléolithiques. Les Dossiers d'Archéologie 142: 2-11.

Debénath, A. 2009. Le Dico de préhistoire. Charente et Charente-Maritime. Paris: Le Croît vif.

Delporte, H. 1970. Figurations anthropomorphes sur bâtons perforés de la grotte du Placard (Charente). Antiquités Nationales 2: 5-13.

Douche, C. 2004. Les industries sur matières dures animales du site du Placard (Charente) conservées à l'Institut de Paléontologie humaine et au Musée de l'Homme. Contribution à la valorisation des collections du Muséum national d'Histoire naturelle. Unpublished Ph.D. Dissertation. Paris: Muséum national d'Histoire naturelle.

Eriksen, B.V. 2002. Fossil mollusks and exotic raw materials in Late Glacial and Early Postglacial find contexts: A complement to lithic studies, in B.V. Eriksen and L.E. Fisher (eds) Lithic Raw Material Economies in Late Glacial and Early Postglacial Europe (B.A.R. International Series, 1093): 27-52. Oxford: Archaeopress.

Fermond, J. 1873. Stations humaines préhistoriques. Notice sur les différents âges de la pierre et sur l'âge du bronze dans la vallée de la Tardoire. Angoulême: Imprimerie de la Charente.

Fermond, J. 1874. Notice sur les âges de la pierre et du bronze dans la vallée de la Tardoire (Charente). Matériaux pour l'Histoire primitive et naturelle de l'Homme (2e série) IX/V: 5-15.

Fischer, P. 1879. Coquilles vivantes et fossiles recueillis dans les abris sous roche de la Charente par l'abbé Bourgeois et par MM. Fermond et de Maret. Bulletin de la Société Géologique de France (3e série) VII: 396.

Genet-Varcin, É. 1968. Objets ouvrés inédits provenant de la grotte du Placard (Charente). L'Anthropologie (Paris) 72/5-6: 537-544.

Houmard, C. 2003. Réflexions sur les têtes de projectiles rainurées d'après l'étude du site de La Garenne (Indre). Préhistoire Anthropologie Méditerranéennes 12: 165-172.

Houmard, C. and É. Jacquot 2009. Des têtes de projectile composites à "La Garenne", in J. Despriee, S. Tymula, and A. Rigaud (eds) Données récentes sur le Magdalénien de "La Garenne (Saint-Marcel, Indre) et la place du Magdalénien "à navettes" en Europe (Bulletin de l'ASSAAM, Special Issue): 137-150. Argenton-surCreuse: Archéologie du Val de Creuse en Berry.

Jochim, M.A. 1987. Late Pleistocene Refugia in Europe, in O. Soffer (ed) The Pleistocene Old World: Regional Perspective (Interdisciplinary Contributions to Archaeology): 317-332. New York: Plenum Press.

Langley, M.C. 2015. Investigating maintenance and discard behaviours for osseous projectile points: A Middle to Late Magdalenian (c. 19,000-14,000 cal. BP) example. Journal of Anthropological Archaeology 40: 340-360.

Langley, M.C., J.-M. Pétillon and M. Christensen 2016. Diversity and Evolution of Osseous Hunting Equipment during the Magdalenian (21,000 14,000 cal BP), in M.C. Langley (ed) Osseous Projectile Weaponry: Towards an Understanding of Pleistocene Cultural Variability (Vertebrate Paleobiology and Paleoanthropology): 143-159. Dordrecht: Springer.

Leroy-Prost, C. 1977. Quelques éléments d'industrie osseuse de la grotte du Placard (Charente). L'Anthropologie (Paris) 81: 481-494.

Lompré, A. 2003. Une nouvelle étude technofonctionnelle appliquée à un ensemble magdalénien de bâtons percés. Préhistoire Anthropologie méditerranéennes 12: 147-163.

Maret, A. de 1878. Fouilles dans la grotte du Placard (Charente). Bulletin monumental (5e série) VI: 42-47.

Maret, A. de 1879. Fouilles dans la grotte du Placard (Charente). Tours, 1878 (extrait du Bulletin monumental). Matériaux pour l'histoire primitive et naturelle de l'Homme (2e série) X: 33-34.

Maret, A. de 1880. Stations préhistoriques de la grotte du Placard, près de Rochebertier (Charente), in Congrès Archéologique de France, XLVI ${ }^{\circ}$ Session, Vienne, 1879: 162-178. Paris: Champion. 
Maret, A. de 1881. Fouilles de la grotte du Placard près de Rochebertier (Charente). Matériaux pour l'histoire primitive et naturelle de l'Homme 12: 229-233.

Mons, L.1976. Les bâtons perforés de la grotte du Placard (Charente) au Musée des Antiquités Nationales. Antiquités Nationales 8: 11-20.

Mons, L. 1980. Essai d'analyse et de classification des poinçons des gisements solutréens et magdaléniens du Placard (Charente), de Laugerie-Basse et de la Madeleine (Dordogne). Bulletin de la Société Préhistorique Française 77/10-12:317-327.

Mons, L. and D. Kandel 2000. Décors significatifs sur les sagaies du Paléolithique supérieur, in C. Bellier, P. Cattelain and M. Otte (eds) La chasse dans la Préhistoire/Hunting in Prehistory. Actes du Colloque international de Treignes, 3-7 octobre 1990 (ERAUL, 51/ Anthropologie et Préhistoire, tome 111/Artefacts, 8): 376-386. Liège: Service de Préhistoire, Université de Liège.

Mons, L. and D. Stordeur 1977. Des objets nommés "lissoirs" de la grotte du Placard (Charente). Antiquités Nationales 9: 15-25.

Mortillet, A. de 1906. Deux curieuses pièces de la Grotte du Placard (Charente). Bulletin de la Société Préhistorique Française III/10: 431-434.

Mortillet, A. de 1907. La Grotte du Placard (Charente) et les diverses industries qu'elle a livrées, in Congrès Préhistorique de France, Compte-Rendu de la $2^{\circ}$ session, Vannes, 1906: 241-265. Paris: Schleicher Frères.

Oakley, K. 1965. Folklore and fossils part II. Antiquity 39: 117-125.

Octobon, E. 1926. Inspection académique de la Charente. La préhistoire et l'instituteur. Etudes locales-Bulletin de la Société charentaise des études locales VII/65: 193238.

Patte, E. 1941. Le Paléolithique dans le Centre-Ouest de la France. Charente, Charente-Inférieure, Deux-Sèvres, Haute-Vienne, Indre, Indre-et-Loire, Vendée, Vienne. Paris: Masson et Cie.

Pétillon, J.-M. 2006. Des Magdaléniens en armes. Technologie des armatures de projectile en bois de cervidé du Magdalénien supérieur de la Grotte d'Isturitz (Pyrénées-Atlantiques). Treignes: Centre d'Etudes et de Documentation Archéologiques.

Pétillon, J.-M. 2008. First evidence of a whale-bone industry in the western European Upper Paleolithic: Magdalenian artifacts from Isturitz (PyreneesAtlantiques, France). Journal of Human Evolution 54: 720-726.
Pétillon, J.-M. 2013. Circulation of whale-bone artifacts in the northern Pyrenees during the late Upper Paleolithic. Journal of Human Evolution 65: 525-543.

Pétillon, J.-M., O. Bignon, P. Bodu, P. Cattelain, G. Debout, M. Langlais, V. Laroulandie, H. Plisson and B. Valentin 2011. Hard core and cutting edge: Experimental manufacture and use of Magdalenian composite projectile tips. Journal of Archaeological Science 38: 1266-1283.

Pétillon, J.-M. and C. Letourneux 2003. Au retour de la chasse. Observations expérimentales concernant les impacts sur le gibier, la récupération et la maintenance des projectiles dans le Magdalénien supérieur d'Isturitz. Préhistoire Anthropologie Méditerranéennes 12: 173-188.

Pignolet, A. 2013. Nature et origine de l'ivoire utilisé par les artisans préhistoriques - Exemple du Placard (Charente ; Magdalénien). Master's Thesis. Paris: Department of Prehistory, Muséum National d'Histoire Naturelle.

Rigaud, A. 2006. Étude technologique des baguettes demirondes de Labastide (Hautes-Pyrénées). Archéologie des Pyrénées occidentales et des Landes 25: 229-246.

Roche, J. 1963. Os incisé provenant de la grotte du Placard (Charente). Bulletin de la Société Préhistorique Française LX/1-2: 75-78.

Taborin, Y. 1972. Les Cardium triforés du Placard. Bulletin de la Société Préhistorique Française 69/9: 269-273.

Taborin, Y. 1992. Les espaces d'acheminement de certains coquillages magdaléniens, in J.-P. Rigaud, H. Laville and B. Vandermeersch (eds) Le Peuplement Magdalénien. Paléogéographie physique et humaine. Actes du colloque de Chancelade, 10-15 octobre 1988 (Documents préhistoriques, 2): 417-429. Paris: Editions du C.T.H.S.

Taborin, Y. 1993. La parure en coquillage au Paléolithique. Paris: CNRS Editions.

Weniger, G.C. 1992. Function and form: An ethnoarchaeological analysis of barbed points from northern hunter-gatherers, in F. Audouze (ed) Ethnoarchéologie: Justification, problèmes, limites: 257268. Juan-les-Pins.

Weniger, G.C. 2000. Magdalenian barbed points: Harpoons, spears and arrowheads, in C. Bellier, P. Cattelain and M. Otte (eds) La chasse dans la Préhistoire/ Hunting in Prehistory. Actes du Colloque international de Treignes, 3-7 octobre 1990 (ERAUL, 51/Anthropologie et Préhistoire, tome 111/Artefacts, 8): 79-87. Liège: Service de Préhistoire, Université de Liège. 